Aino Salimäki and Sini Jämsén. Perceptions of politics and fairness in merit pay. Journal of Managerial Psychology, in press.

(C) 2009 by authors and ( 2009 Emerald Group Publishing

Preprinted with permission.

http://www.emeraldinsight.com/jmp.htm 


\title{
PERCEPTIONS OF POLITICS AND FAIRNESS IN MERIT PAY
}

Aino Salimäki \& Sini Jämsén

Helsinki University of Technology

\begin{abstract}
Author Note
The first author would like to acknowledge the financial support received from Emil Aaltonen Foundation for the preparation of this manuscript. Mari Huuhtanen, Katriina Karkulehto, Virpi Karppinen, and Carita Lahti contributed to the data collection. We are indebted to Jason D. Shaw and Chad Brinsfield for their helpful comments on the paper. An earlier version of this paper was presented at the 2007 Annual Meeting of the Academy of Management.

Correspondence should be directed to: Aino Salimäki, Department of Industrial Engineering and Management, P.O Box 5500, 02015 TKK, Finland. Email: aino.salimaki@tkk.fi; Fax: (358) 9- 4513665.
\end{abstract}

In press at Journal of Managerial Psychology

(C) Emerald Group Publishing Limited

$\underline{\text { www.emeraldinsight.com/jmp.htm }}$ 


\begin{abstract}
Purpose: Employee perceptions of politics and fairness were studied in a work setting where a new merit pay system had recently been implemented.

Design/methodology/approach: Based on the literature on organizational politics, equity, procedural justice, and social exchange theory, we expected that employee perceptions of politics and fairness are associated with the perceptions of merit pay effectiveness. The results are based on employee survey responses from three governmental organizations $(\mathrm{N}=367)$ that had implemented analogous merit pay systems.
\end{abstract}

Findings: Hierarchical moderated regression results indicated that perceptions of politics and fairness distinctively and interactively predicted whether the pay system was perceived effective in achieving its objectives. The results suggest that some forms of politics in performance appraisals (e.g., compression) might be perceived less detrimental than others (e.g., favoritism). In a high politics environment, the pay system effectiveness varied as a function of the level of distributive justice. Voice in the pay system development only mattered in a situation where there was a low level of organizational politics.

Research implications/limitations: One of the main limitations of this study is its reliance on cross-sectional data. Future research should complement employee perceptions about pay system effectiveness with objective data from the organizations studied. Research on the effect of contextual factors, such as national culture on the motives in and reactions to organizational politics, is desired.

Practical implications: The result suggests that the adopted merit pay systems were not ineffective or detrimental per se, but that the effectiveness varied as a function of the established political and fairness climates at different levels of the organization. 
Originality/value: This study contributes to the discussion on what are the conditions under which politics and fairness are antithetical, and when they are interactively associated with outcomes.

Keywords: Merit pay, Performance appraisal, Organizational politics, Fairness, Social exchange, Organizational effectiveness

Paper type: Research Paper 
Merit pay refers to the process of distributing employee pay increases, based on how well each employee performs at work - often determined by supervisory performance appraisal (Heneman, 1992). Despite the overall popularity of merit pay practices and wide support for the principle of paying for individual performance, researchers are troubled by the fact that merit pay seems to often be ineffective in producing the desired outcomes, such as enhanced motivation and productivity (Heneman and Werner, 2006; Gerhart and Rynes, 2003; Rynes et al., 2005). Thus, most employees like the idea of being compensated based on their performance, but are often suspicious about whether a merit pay system has any motivational value in practice because of the numerous implementation problems (Marsden and Richardson, 1994; Harris, 2001). These problems include the difficulty in creating measures for individual performance in interdependent work contexts, limited pay budgets available for merit increases because of the annuity effect (merit increases become fixed part of salary), as well as problems getting supervisors to provide credible performance assessments for administrative purposes (for a discussion, see Campbell et al., 1998; Beer and Cannon, 2004; Perry et al., 2008; Kellough and Lu, 1993).

Research has demonstrated that the implementation of merit pay programs can suffer from a number of barriers related to the performance assessment and pay allocation that may impede its intended usefulness. Both the subjective nature of performance appraisals and the use of those appraisals for administrative purposes (such as pay and promotion) can facilitate different forms of bias in performance appraisal (e.g., Prendergast and Topel, 1996), which results in inaccurate ratings. These biases in performance appraisal, as well as biased pay allocations, can be 
viewed as violations of organizational justice, and/or as forms of organizational politics.

Indeed, research and theory on fairness and politics has identified conditions under which merit pay practices are likely to promote hoped-for and unanticipated outcomes. It is notable, however, that the two lines of literature have developed relatively distinctively, and only recently have there been attempts to integrate them (Ferris et al., 1995). Subsequent research has empirically distinguished the constructs by showing that they have somewhat different antecedents and consequences (Andrews and Kacmar, 2001; Aryee et al., 2004). Furthermore, some recent research has argued and shown that these constructs interact to produce outcomes (Byrne, 2005; Harris et al., 2007). This paper draws from these recent developments and argues that (1) some forms of politics in merit pay systems are more detrimental than others, and (2) employee perceptions of politics and fairness are distinctively and interactively associated with the effectiveness of merit pay systems.

This study makes two important contributions to the literature. First, it enhances our understanding of employee perceptions of politics in merit pay systems. Second, and most importantly, it advances our knowledge on the conditions under which politics and fairness are antithetical, and when they are interactively associated with outcomes. As Harris et al. (2007) note, this is an important topic to study as politics and fairness are ubiquitous in organizations and rarely occur in isolation from one another. Our research material was collected from a naturally occurring pay system change in the Finnish governmental sector. In the new pay system, pay was partly determined by employees' performance appraisals. The system was based on a collective bargaining agreement, and implemented almost simultaneously in three governmental organizations that had analogous operations. We examine to what 
extent fairness and politics explain the fact that the system was deemed somewhat effective (i.e., having positive, intended effects) in one of the organizations, but having somewhat negative, unanticipated effects in the other two organizations.

\section{THEORETICAL FOUNDATIONS}

\subsection{Defining Organizational Politics}

Organizational politics has the potential to have widespread impact on the effectiveness and efficiency of organizations through various organizational processes, such as performance appraisal, resource allocation, and managerial decision-making (for a review, see Kacmar and Baron, 1999). The vast majority of research on organizational politics views it as a negative phenomenon, arguing that perceptions of organizational politics stimulate negative, anxiety-provoking reactions. According to recent meta-analytic studies, a high level of perceptions of politics is negatively associated with job satisfaction and organizational commitment, and positively related to job stress and turnover intentions (e.g., Miller et al., 2008; Chang et al., in press). However, some scholars have noted that organizational politics is necessary for the survival of the organization and those who operate in them, and can sometimes be perceived to be benefiting the organization as a whole (e.g., Pfeffer, 1981; Ammetera et al., 2002). Accordingly, the aims of organizational politics have been classified as follows: (a) to protect and/or enhance an individual's self-interests, and/or (b) to further the interests or goals of another person or group (Altman et al., 1985).

Political activities are likely to manifest themselves in settings in which: (a) resources are scarce (creating a motive for political actions), (b) the appropriateness of certain courses of action is sufficiently ambiguous so as to allow discretionary behavior (creating an opportunity for political actions) (Ferris et al., 1996), and (c) 
one is able to control resources (creating a means for political actions to occur). Considering that means, motive, and opportunities frequently coincide in situations in which people decide about compensation, it is not surprising that political behavior occurs in such contexts (Bartol and Martin, 1990). Still, Gupta and Jenkins (1996) report that organizational decision-makers often express surprise when their compensation systems do not achieve their goals, and further, reactions to these failures often focus on structural changes in the system, rather than on the sociopolitical factors that might create problems in the first place.

In merit pay systems, political behavior can enter into the performance appraisal conducted by the immediate supervisor (Tziner et al., 1996). When conducting the performance appraisal, the supervisor may take into account its impact on many factors, such as his or her own reputation, the motivation of an individual, group dynamics, and the pay budget (Longenecker et al., 1987). In line with Poon (2004), we distinguish between two forms of political behavior in performance appraisal that are likely to stem from different agendas. In addition, politics can also enter into the actual decisions on pay (Ferris and Kacmar, 1992; Kacmar and Carlson, 1997). The performance appraisal scores and the level of raises are not always directly linked. In such situations, the immediate supervisor does not make the final pay decisions, but rather they are made at higher levels (such as in the case of our study, the upper management participated in the decisions).

\subsection{Politics in Performance Appraisal}

Previous research has shown that when supervisors believe that appraisals are used for administrative decisions, such as promotion and pay raises, they tend to pay more attention to the performance appraisal process (Tziner et al., 2005). The research has also found that the heightened attention does not, however, guarantee 
increased accuracy in the performance appraisals. Murphy and Cleveland (1995) argue that performance appraisal can be considered goal-directed behavior, where a range of characters of individuals, organizations, and performance measurement systems lead raters to adopt different sets of goals when completing a performance appraisal. When raters complete performance appraisals, they have specific (and possibly multiple) goals in mind, and intend to provide ratings that are consistent with these goals (Murphy et al., 2004). This means that raters who pursue different goals when completing performance appraisals tend to give different ratings, even when they have observed the same performance.

Adoption of a merit pay practice where performance appraisals are used as a basis for compensation decisions often enhance the (reward) power of the immediate supervisors (and conversely, the withdrawal of a merit pay practice subsequently reduces this power, see Greene and Podsakoff, 1981). However, the use of performance appraisals as a basis for pay decisions can be of concern because the subjective nature of performance appraisals present threats to the accuracy of those appraisals, such as those stemming from affective influences, liking, and favoritism (for reviews, see, Arvey and Murphy, 1998; Lefkowitz, 2000; Levy and Williams, 2004; see also Prendergast and Topel, 1996; Tsui and Barry, 1986). Favoritism can be considered an unintended cognitive bias (assuming that raters are motivated to rate accurately), or goal directed behavior intended to gain, for example, employee goodwill (Longenecker et al., 1987).

Viewing favoritism as a goal-directed behavior, one could presuppose that it is likely to enter into performance appraisals especially when supervisors are motivated to protect and/or enhance their self-interests. Research has found that supervisors are likely to deliberately distort the performance appraisal scores when 
they have a high need for power, they are high in Machiavellianism, have low selfefficacy, are not highly committed to the organization, and purport to gain control over organizational behavior and resources (Tziner et al., 1997; Tziner et al., 1996; Tziner, 1999). This in the context of merit pay systems can mean that supervisors ensure high performance appraisal scores for those employees they are dependent on (Bartol and Martin, 1988, 1990). Thus, from the supervisor's perspective, favoritism in performance appraisals might facilitate the retention of those employees they consider the most important resources (since these employees are likely to receive higher pay increases). However, generally from the subordinate's perspective, these 'affective motives' present uncertain and even ineffective leadership. Therefore, we expect that distortions of performance appraisal scores based on favoritism will be perceived as self-serving behavior that has a negative impact on employees' perceptions of pay system effectiveness.

Hypothesis 1: Perceptions of favoritism in performance appraisal will be negatively related to perceptions of pay system effectiveness.

Poon (2004) proposes that in some cases employees might consider manipulations of performance ratings as legitimate behavior, for example, when ratings are compressed in anticipation of evenly distributed pay raises that would preserve group climate or encourage future performance. Longenecker et al. (1987) found that in certain circumstances, managers believed that it was in their best interests and justifiable to make inaccurate performance ratings in order to maintain a positive work group climate or avoid negative outcomes of the rates. Furthermore, it has been shown if the rater intends to use the performance appraisal as a means of motivating his or her subordinates, he or she will give ratings that are most likely to 
encourage future performance, not necessarily ratings that accurately reflect past performance (Murphy et al., 2004).

The manipulations of performance ratings for motivational purposes, such as making subordinates look good in order to maximize benefits for them, are generally in the best interests of the employees. As supervisors compress performance appraisals for motivational purposes, this political behavior might be perceived to represent managerial discretion exercised to ensure the attainment of goals and potentially benefit the individual employee and even the organization as a whole. As a result, it might be perceived an effective use of the pay system.

Hypothesis 2: Perceptions of compression in performance appraisal will be positively related to perceptions of pay system effectiveness.

\subsection{Politics in Pay Decisions}

Under any type of compensation system, employees can perceive that politics play a role in how pay raises are assigned to employees by organizational decision-makers (Kacmar and Ferris, 1991; Ferris and Kacmar, 1992; Kacmar and Carlson, 1997). In merit pay systems this might be the case especially if performance appraisal scores and the level of raises are not directly linked. "Loose coupling" of performance appraisal scores and assigned pay levels is a common practice in organizations to exert control on pay budgets, and sometimes even advocated as a way of overcoming certain problems with pay for performance, such as focusing on only those activities for which there are rewards (e.g., Campbell et al., 1998). However, at the same time, loose coupling might offer an opportunity for organizational politics to enter into the pay for performance process. Accordingly, we propose that the more politics is perceived to enter into pay decision-making, the less effective the system will be deemed to be in achieving its objectives. 
Hypothesis 3: Perceptions of politics in pay decisions will be negatively related to perceptions of pay system effectiveness.

\subsection{Fairness of Pay: Equity and Procedural Justice Theory}

Employees usually like the idea of being compensated for their performance (i.e., pay equity) in comparison to distribution of rewards equally or according to the needs of the employees (e.g., Chen, 1995; Chiang and Birtch, 2005; Mamman et al., 1996). The most prominent explanation for this stems from equity theory (Adams, 1965) according to which employees make cognitive evaluations of the ratio of their inputs and returns, and compare that ratio to that of others. For this reason perceived pay equity (or distributive justice, cf. Colquitt, 2001) is highly associated with pay satisfaction (Williams et al., 2006). Distributive justice refers here to the extent to which employees perceive the pay system rewards them fairly. There is a great deal of evidence that perception of low distributive justice is related to unfavorable attitudes and behavior at workplace (for a review, see, Colquitt et al., 2001; Cohen-Charash and Spector, 2001; Conlon et al., 2005).

Hypothesis 4: Perceptions of distributive justice will be positively related to perceptions of pay system effectiveness.

Stemming from the theory of procedural justice by Thibaut and Walker (1975), both process control (i.e., control over the processes leading to decisions) and decision control (i.e., control over decision outcomes) are important for fairness perceptions. Thus, this control-oriented theory of procedural justice predicts that individuals will be more satisfied with a procedure that provides them with control (Shapiro and Brett, 2005). Voice is defined here as the extent to which an employee expressed his or her views to decision-makers during the pay system development (e.g., Cox, 2000; Jenkins and Lawler, 1981; Fernie and Metcalf, 1995; Kleingeld et 
al., 2004). Aligned with previous literature, it is posited that employee voice (in the form of participation) in pay system development will enhance perceptions of pay system effectiveness.

Hypothesis 5: Perceptions of voice in pay system development will be positively related to perceptions of pay system effectiveness.

\subsection{Politics and Fairness: Social Exchange Theory}

While research has demonstrated empirically that politics and fairness are not just antithetical, but separate constructs (Andrews and Kacmar, 2001), little research has examined which one is more relevant (Aryee et al., 2004), or whether they would interact in predicting outcomes, such as job performance, citizenship behavior, job satisfaction, and turnover intentions (Byrne, 2005; Harris et al., 2007). The previous studies on the topic have provided support for the importance of examining perceptions of justice and politics at the same time. Results suggest that fairness can sometimes reduce the negative effects of politics (e.g., Byrne, 2005; Harris et al., 2007).

This literature has drawn from social exchange theory that considers feelings of reciprocity to be at the core of employment relationships. Social exchange relationships develop between two parties through a series of mutual, although not necessarily simultaneous, exchanges that yield a pattern of reciprocal obligation in each party (Blau, 1964). Thus, the workers provide their talents and motivation in the hope of earning something in return, such as pay and power (Randall et al., 1999). In the workplace, social exchange relationships evolve when employers "take care of employees," which thereby prompts beneficial consequences. Here, organizational justice may reduce ambiguity and serve as a source of control while strengthening an employee's social exchange with the organization (Harris et al., 2007). 
A merit pay system can be considered an organizational intervention that stimulates a social marketplace, where individuals engage in several transactions to obtain a favorable return for their investment. Merit pay creates competitions where some win (i.e., get merit increases) and some lose (i.e., don't get increases). In a highly political environment the effect of unfair pay might be emphasized: As the outcome of this competition becomes salient, those who lose, are likely to experience an even more pronounced effect from politics (on their social exchange consideration) if they do not get a favorable return on their investment. Thus, if the employees perceive that they did not get what they deserved (i.e., a low degree of distributive justice), they are likely to perceive that the pay system is ineffective to motivate them to achieve organizational objectives. Conversely, in situations where the employees feel they personally benefited from the situation (i.e., high degree of distributive justice), the association between organizational politics and pay system effectiveness may be attenuated.

Hypothesis 6: The relationship between perceptions of politics in pay decisions and perceptions of pay system effectiveness will be moderated by perceptions of distributive justice. (a) The pay system will be perceived least effective when employees experience a high level of politics and a low level of distributive justice, (b) Conversely, the pay system will be perceived most effective when employees experience a low level of politics and a high level of distributive justice.

According to social exchange theory, reciprocity generally produces better work relationships than negotiations and allows for individuals to be more trusting of, and committed to, one another (Cropanzano and Mitchell, 2005). According to Ferris et al. (1995) in a politicized environment where total organizational political activity is high but only few people engage in political behavior, the power differential leads 
to a sense of helplessness on the part of most employees. Thus, when voice (a form of negotiation power) is low but politics high, it is unlikely that a pay system would be perceived effective in producing positive outcomes in the organization. On the contrary, in a situation where there is a low level of politics but a high level of voice, the pay system might be perceived effective since employees perceive control over the situation (Ferris et al., 1989; Harris and Kacmar, 2005; Ferris et al., 1996) and thus, are more willing to reciprocate in making an effort to achieve the goals of the organization.

Hypothesis 7: The relationship between perceptions of politics in pay decisions and perceptions of pay system effectiveness will be moderated by perceptions of voice in pay system development. (a) The pay system will be perceived least effective when employees experience a high level of politics and a low level of voice.

(b) Conversely, the pay system will be perceived most effective when employees experience a low level of politics and a high level of voice.

In summary, this study will examine how perceptions of politics and fairness are related to merit pay effectiveness. Based on the literature reviewed above, we argue that (1) employees make sense of the different forms of (or motives for) organizational politics that cause inaccuracy in the merit pay process (i.e., performance appraisals and pay decisions). Moreover, some of these motives might be more acceptable and even considered effective in furthering organizational goalattainment. Based on social exchange theory, advantageous and fair transactions are assumed to stimulate reciprocity (Cropanzano and Mitchell, 2005). Following, we argue that (2) the pay system will be perceived most effective when there is a low level of organizational politics and high level of distributive justice and/or voice. 
.Thus, in our model (see Figure 1) social exchange consideration is an intervening (and unmeasured) variable.

[INSERT FIGURE 1 ABOUT HERE]

\section{METHODOLOGY}

\subsection{Participants and Procedure}

The data were collected from three organizations in the central government in Finland. Compensation arrangements in the Finnish public sector are in a state of transition from traditional "mechanical" pay systems based on job grade and seniority, to pay for performance systems that recognize and reward merit. The new pay systems are comprised of two components - a job-based component derived from the appraised value of the job to the organization (job evaluation), and a merit pay component derived from supervisor appraisals of individual performance. However, in this context the supervisors may only be charged with recommending raise levels, but a higher-level organizational decision-maker or committee may make the final pay raise decisions. Under the new guidelines, the merit pay component could in principle constitute as much as $50 \%$ on top of the job-based pay.

The participating organizations were similar in their basic operations, and had experienced analogous pay reforms. The new pay system was introduced in 2002 or 2003 and had been in use from two to three and a half years at the time the data were collected. We mailed surveys with a postage-paid return envelope to all employees in the three organizations, excluding senior managers, trainees, and employees with short-term (6 months or less) contracts to whom the system did not apply. A cover letter explained the purpose of the study and gave an assurance of confidentiality.

Altogether 906 questionnaires were mailed and 375 were returned. Response rates for the three organizations were $48 \%$ (157/320), 39\% (109/270), and 34\% 
(109/316). An overall $41 \%$ response rate is just within the acceptable range of $60 \pm 20$ norm provided by Baruch (1999). Eight questionnaires were omitted from the analyses because of missing data. Thus, the final sample size was 367. More than half $(65 \%)$ of the participants were women, the average age was 48 years with a range from 24 to 65 , and 52\% had higher-degree level tertiary education (i.e., a Master's degree).

\subsection{Survey Measures}

Politics. As there are no scales that would consider the different aspects of politics in the merit pay process, we construed a measure for the study. We selected and adapted six items from the questionnaire for measuring perceived political considerations in performance appraisal (the QPCPA: Tziner et al., 1996, or PCPAQ: Tziner et al., 1997) and three items depicting politics in pay decisions from the perceptions of politics scale (the POPS; Ferris and Kacmar, 1992; Kacmar and Carlson, 1997). We translated the selected items from English to Finnish and pilottested the scale. To simplify the measurement, all items were measured using a 5point Likert scale (from 'very strongly disagree' to 'very strongly agree'). A full listing of the scale we construed based on the selected QPCPA and POPS items can be found in Appendix A. The internal consistencies of politics in pay decisions $($ Cronbach's alpha $=.79)$, favoritism in performance appraisal $($ Cronbach's alpha $=$ $.72)$, and compression in performance appraisal (Cronbach's alpha $=.76)$ scales were acceptable (cf. Nunnally and Bernstein, 1994).

Pay fairness. Voice in pay system development was measured using 4 items from a measure developed by Daly and Geyer (1994). The respondents were asked when the pay system was developed in their organization, whether, for example, they were asked for their opinion (see for the listing of the items in Appendix A). The 
internal consistency of the measure (Cronbach's alpha $=.80$ ) was acceptable.

Distributive justice was measured using the 6-item Distributive Justice Index by Price and Mueller (1986). The items ask respondents to indicate the extent to which they have been fairly rewarded in view of their performance, effort, experience, responsibilities, education and training, and job stress. The internal consistency of the scale was good (Cronbach's alpha .96). Both variables were measured on a 5-point Likert scale (from 'very strongly disagree' to 'very strongly agree').

Pay system effectiveness. A 5-item measure was developed for this study to measure the perceptions of pay system effectiveness (Cronbach's alpha $=.93)$. We asked the respondents: In your opinion, how does the new pay system affect the following issues? Respondents reported their perceptions of the effectiveness of the pay system on a 5-point Likert scale in terms of having a 'very positive effect' $(+2)$, 'somewhat positive effect' (+1), 'no effect' $(0)$, 'somewhat negative effect' (-1), or 'very negative effect' (-2) on the following: the achievement of organizational objectives, the success of the organization, productivity, the quality of services, and employee developmental opportunities..

\subsection{Response Bias Check}

We were able to obtain archival information on gender and age, in addition to pay-related information (job-based pay, pay for performance proportion, and pay changes) for non-responders in our study. We used t-tests to examine the extent to which this summary information differed from the characteristics of our sample. These tests revealed no significant differences between respondents and nonrespondents.

\subsection{Control Variables}


We controlled for the job-based pay as it reflects the hierarchical level of the job in the organization. The average monthly job-based pay was 2,560 euro with a range from 1,430 euro to 5,026 euro. We also controlled for the person's merit pay proportion as it reflects the horizontal pay position on a certain job level. The average merit pay proportion was $25 \%$ on top of the job-based base pay, ranging from 0 to $40 \%$. The pay data were obtained from the Finnish government and matched to the survey data with a randomly assigned code number attached to the survey.

In this context it was also necessary to control for the impact of the pay system change on the person's pay. Namely, the new pay system suggested lower pay levels for some employees (11\% of the employees). These employees would not directly experience a pay cut, but there was an indirect effect on these employees' pay prospects, since they would first have to catch up with the expectations for the current pay levels and then exceed those in order to receive a pay increase in future. We formed a 'pay change' variable that accounted for the amount of the pay increase or an indirect pay cut the person experienced.

These three 'pay position' variables (job-based pay, merit pay, and pay change) were controlled for as they could potentially affect the employee's perceptions of the effectiveness of the pay system such that those with higher pay might also hold more favorable perceptions of the pay system effectiveness. This is expected, as research has found that the favorability of feedback (Stone and Stone, 1984; Stone and Stone, 1985) and performance appraisals (Dipboye and dePontbriand, 1981) might impact beliefs about them. To conduct more rigorous statistical tests of the hypotheses, we also controlled for organization, age, gender, and education of the respondents, as these variables may be associated with the perceptions of pay system effectiveness. 


\subsection{Measurement Model}

Before hypothesis testing, we performed a confirmatory factor analysis in Amos 16.0 to explore the structural validity of the politics and fairness measures. Following Poon (2004), we expected that perceptions of politics in performance appraisal would be a two-dimensional construct: what we call here favoritism and compression in performance appraisal. In addition, we expected that politics in pay decisions would load on a separate factor. Voice in pay system development was expected to be distinct from distributive justice perceptions. According to confirmatory factor analysis results ${ }^{1}$, the 5 -factor model provided an acceptable fit (cf. $\mathrm{Hu}$ and Bentler, 1999) to the data $\left[\chi^{2}(d f=144)=431.47, \mathrm{NFI}=.89, \mathrm{CFI}=.92\right.$, RMSEA $=.07]$. Furthermore, the $\chi^{2}$ difference test between the 5-factor model and 4factor $\left[\Delta \chi^{2}(d f=3)=173.48, p<.001\right]$, as well as the 3 -factor model $\left[\Delta \chi^{2}(d f=6)=\right.$ $419.45, p<.001]$ indicated highly significant differences, lending support to the superiority of the 5-factor model.

\section{RESULTS}

Correlations between demographics and survey scales are reported in Table 1. There are significant mean level differences between the three organizations (according to one-way ANOVA in SPSS 16.0) in perceptions of politics in pay decisions, voice in pay system development, distributive justice, and pay system effectiveness, but not with regard to the perceptions of politics in performance appraisal (see Table 2). It is notable that the pay system was perceived on average as not only ineffective, but having negative, undesired effects in the first and second

\footnotetext{
${ }^{1}$ We estimated five alternative models: 1-factor model (where all items load on single factor), 2-factor model (where politics -items load on one factor and fairness -items on second factor), 3-factor model (where politics -items are expected to load on two factors and fairness -items on third factor), 4-factor model (where politics- items are expected to load on two factors and fairness -items on two factors), and the expected 5-factor model (where politics -items are expected to load on three factors and fairness -items on two factors). The models account for correlations between factors. The results are available from the authors upon request.
} 
organizations (means -.26 and -.14 on a scale from -2 to +2 ). However, the pay system was perceived on average as somewhat effective in the third organization (mean .08). [INSERT TABLES 1 AND 2 ABOUT HERE]

Hierarchical regression analyses (in SPSS 16.0) were used to analyze the relations between perceptions of politics, fairness, and pay system effectiveness (see Table 3). The control variables: organization, age, gender, education, and the pay position of the respondent (job-based pay, merit pay, and pay change) were entered in the first step. The politics and fairness related variables were centered, and entered in the second step. Perceptions of favoritism in performance appraisal $(\beta=-.14, p<.05)$, politics in pay decisions $(\beta=-.42, p<.001)$, and distributive justice $(\beta=.17, p<.01)$ significantly predicted pay system effectiveness. However, perceptions of compression in performance appraisal $(\beta=.02$, n.s. $)$ and voice in pay system development $(\beta=.06, n . s$.$) did not significantly predict pay system effectiveness.$ Thus, Hypotheses 1, 3, and 4 are supported but Hypotheses 2 and 5 are not supported. [INSERT TABLE 3 ABOUT HERE]

The interaction terms were entered in the third step. As both of the interaction terms were statistically significant, we plotted the interactions (see Figures 2 and 3). In line with Hypothesis 6 (a), pay system effectiveness was lowest (actually the system was perceived to have negative effects) when there was a high level of politics in pay decisions and a low level of distributive justice. The pay system was perceived most effective when there was a low level of politics in pay decisions regardless of the level of distributive justice, providing only partial support for Hypothesis 6 (b). In line with Hypothesis 7 (b), the pay system effectiveness was highest (system is perceived to bring about positive results) when there was a low level of politics in pay decisions and a high level of voice. When there was a high 
level of politics in pay decisions, the pay system was deemed least effective regardless of the level of voice in pay system development. The results provide partial support for Hypothesis 7 (a). In total, politics and fairness variables account for $34 \%$ of the variance in pay system effectiveness.

\section{[INSERT FIGURES 2 AND 3 ABOUT HERE]}

We conducted supplemental post hoc analyses to examine to what extent there are political and fairness sub-climates (Treadway et al., 2005) on the unit level (here 26 units) in addition to the organizational level. According to our analysis (ANOVA in SPSS), there were no significant mean differences in politics in pay decisions and distributive justice on the unit level (in addition to the organizational level, see Table 2). However, there were statistically significant mean differences in voice in pay system development $[F(24,282)=2.09, p<.01]$ and pay system effectiveness $[F(23$, $250)=1.96, p<.05]$ on the unit level (in addition to differences on the organizational level). There were no significant mean differences with regard to favoritism in performance appraisal or compression in performance appraisal among units or organizations, suggesting that these phenomena only occur at the supervisorsubordinate dyad level.

\section{DISCUSSION}

Merit pay systems are often implemented and maintained because they are assumed to be an effective way of attracting, motivating, and retaining employees. The espoused benefits of these plans, their widespread use, and the assumption that they can ultimately increase the performance of organizations have been well documented (Gerhart and Rynes, 2003). Although such systems are designed to motivate job performance and align employer interests with those of employees', the potential for them to also be incubators for political activity raises the possibility that 
their noble purposes may, in actual practice, be subverted by the political behavior of the superiors in their performance appraisal process and the organizational decisionmaking over pay.

One of the main goals of this study was to enhance our understanding of politics in pay for performance systems by studying employee perceptions in a work setting where a new merit pay system had recently been implemented. As Murphy and Cleveland (1995) have noted, the goals being pursued by raters are critically important for understanding the inaccuracy of performance appraisals. We approached the challenge from the employee perspective. We find that in the same fashion as employees have been found to make attributions about the purposes of human resource practices (Nishii et al., 2008), different forms of (or motives for) political behavior that cause inaccuracy in the merit pay process are likely to be perceived as detrimental or neutral by the employees.

According to our results, the higher levels of politics employees perceived in pay decision-making, the less effective the pay system was perceived in achieving its objectives. Also a high level of favoritism in performance appraisal was related to low levels of pay system effectiveness, as expected. However, we expected compression in performance appraisal (such as in anticipation of evenly distributed pay raises that would preserve group climate), would be perceived as effective since it might be considered to further the interests of the employees as individuals or as a group (Altman et al., 1985). We did not find support for this notion, but nevertheless, we would like to emphasize that the compression in performance appraisal was not perceived as having a negative impact on pay system effectiveness either. These results are in line with previous research that found that when employees perceived performance ratings to be manipulated for the purpose of rewarding employees (or 
avoiding negative outcomes for them), and promoting a positive workgroup climate (by avoiding situations that would create resentments and conflicts), their job satisfaction and turnover intention were not affected (Poon, 2004).

The most important goal of our study was to answer the call by Ferris et al. (1995) to explore under what conditions politics and fairness can be considered antithetical (i.e., politics can be considered as a form of bias, a violation of the justice rules), and when they are interactively associated with outcomes. Aligned with previous research, our study supports the contention that organizational politics and fairness are distinct constructs (Andrews and Kacmar, 2001; Aryee et al., 2004) that interact in predicting social exchange outcomes (Byrne, 2005; Harris et al., 2007), such as the extent to which a pay system is considered effective in motivating goal achievement. First, based on equity and procedural justice theory, we hypothesized that distributive justice and voice in pay system development would predict pay system effectiveness (over and above) politics-variables. We find partial support for this, since distributive justice significantly predicted pay system effectiveness but voice did not.

Second, based on social exchange theory, we expected that politics and fairness would be interactively associated with the effectiveness of the pay system. Aligned with our hypothesis, there was an interaction between organizational politics and distributive justice such that the merit pay system was deemed to have a negative impact when there was both a high level of politics and a low level of distributive justice. There also was a significant interaction between organizational politics and voice in pay system development in predicting pay system effectiveness. Voice mattered in a situation where there was a low level of politics. Previous research has found that voice matters when people expect to have the opportunity to express their 
views to decision-makers, value this freedom, and people perceive their listeners to be treating them respectfully (Shapiro and Brett, 2005). The results of this study suggest that in a highly political environment employees are less likely to believe that authorities are sincere and considerate, and thus, voice is positively related to pay system effectiveness only in a low politics environment.

Taken as a whole, the results of this study suggest that some forms of organizational politics might be perceived as more detrimental than others, and that employee perceptions of pay system effectiveness depends on both politics and fairness. Both longitudinal and comparative research is needed to determine the conditions under which merit pay systems are seen as threats and the conditions under which they are seen as opportunities. For example, Harrell-Cook, Ferris, and Dulebohn (1999) found that individuals who perceive their organizational environments to be highly political engage in political behavior as a mechanism of control through which their situation is made "more bearable". Furthermore, it is possible that in a highly political environment only those employees that behave politically "win" and get pay raises. It is notable that very few studies directly examine exchange processes — or the "black box" of social exchange (Cropanzano and Mitchell, 2005). We hope this study will encourage further research on the impact of the different forms of political agenda on employee social exchange considerations.

\subsection{Limitations and Implications for Future Research}

The findings of this study need to be interpreted with the following limitations in mind. The sample of this study was drawn from a specific context where employees had recently experienced a pay system change, a transfer from a senioritybased pay system one based on merit. In this context, there was a loose coupling between performance appraisals and pay. The role of politics in performance appraisal 
might be emphasized in systems where performance appraisals are directly linked to pay increases. Furthermore, the effect of the national or organizational culture might be an interesting moderator for the study on political behavior and consequences of politics perceptions. For example, Beatty, McCune, and Beatty (1988) demonstrated that U.S. managers were willing to give dispersed increases, whereas the Japanese managers had little variance in pay increases from employee to employee indicating that they believed that a small variation in pay increases would preserve group harmony. In addition, employee reactions to negative feedback (as would be by receiving no merit increase or a small increase) might also vary between cultures (Stone-Romero and Stone, 2002). Future research on the effect of contextual factors, such as national culture on the motives in and reactions to organizational politics, is desired.

The validity of our perceptions of politics measure can be questioned as we selected only certain items from the QPCPA (Tziner et al., 1996) and POPS (Ferris and Kacmar, 1992; Kacmar and Carlson, 1997) scales. Even though confirmative factor analysis and Cronbach's alphas support the validity and reliability of the construed measures, we cannot exclude the possibility of the translation of the items having an impact on the item interpretation, and the exclusion of items from the original scales to have altered the meanings of the dimensions. It is possible that QPCPA is one-dimensional when employed for supervisors (Tziner et al., 1996; Tziner et al., 1997) and multidimensional when employees are asked for their perceptions about the political behavior of superiors (Poon, 2004). Perhaps even more importantly, our politics measure might not have sufficiently captured the different political motives that enter into merit pay systems perceived by the employees. The role of organizational policies, such as whether there is a forced distribution in 
performance appraisals, decisions about compensable factors and sub-factors, choice of compensation decision-makers, sources of external compensation information, internal or external equity, and timing of assessments and reassessments (Gupta and Jenkins, 1996), are some organizational-level factors to consider in future studies.

Our reliance on a single survey also is of concern. Given the cross-sectional nature of the study, we are unable to provide a definite answer regarding the causal effect of politics on pay system effectiveness. Also, since our dependent and independent variables were measured within the same survey, our findings may be influenced by common method bias by creating artificial correlation between the variables (Podsakoff et al., 2003). To help reduce the likelihood of this possibility, the following steps were taken in the survey design and administration: 1) information about the double blind data gathering procedure was communicated to everyone to reduce social desirability, and 2) pilot tests were conducted to reduce survey item ambiguity. Research has also shown that artificial interaction cannot be created by common method variance (Evans, 1985). Instead, true interactions can be deflated. Future research should complement employee perceptions about pay system effectiveness with objective data from the organizations studied. Alternatively, a series of subsequent surveys can be used to reduce common methods bias and resolve issues with potential reverse causality (Podsakoff et al., 2003).

Finally, future research should incorporate moderators, such as employee political skill and engagement in political behavior, in models that aim to explain the role of politics in pay system effectiveness. Altogether, there is a dearth of research on the destructuralization of human resource management systems, and the role of employee political skills, political behavior, and perceptions of politics in the process. We hope more research will emerge on the topic. 


\subsection{Managerial Implications}

Previous research has emphasized the importance of leader motivation in the success of the merit pay and performance appraisal systems (Gabris and Ihrke, 2000). Because of the established reward power in pay for performance systems (Greene and Podsakoff, 1981), they can be used for purposes other than those intended (i.e., carefully measuring employee contributions and basing rewards on those contributions). Dipboye (1995) argues that implementation of highly structured programs associated with a rational strategy of human resource management can lead to political behavior in which decision-makers modify what they perceive as inflexible and even inhumane procedures.

Even if these organizational environments were analogous, and they had implemented the merit pay systems based on the same collective agreement at about the same time, the pay system was perceived as having negative, unintended effects in two organizations, whereas the system was perceived as somewhat effective in the third organization. Since differing mean levels of pay system effectiveness were related to perceptions of organizational politics and fairness, the result suggests that the adopted merit pay systems were not ineffective or detrimental per se but that the effectiveness varied as a function of the established 'political' and 'fairness' climates (Treadway et al., 2005) at different levels of the organization. Situational factors (Valle and Perrewe, 2000), such as job ambiguity, scarcity of resources, and trust in supervisors (Poon, 2003, 2006) might have accounted for the differences in these climates between the organizations.

On the whole, our study provides a good example of how dangerous it is to implement a merit pay practice if employees perceive appraisals are based on favoritism, and pay decisions are based on political agendas. If employees feel that the 
pay decisions are based on politics instead of their performance, they are likely to become cynical as to whether the pay system would promote positive outcomes such as productivity and employee developmental opportunities. The beliefs of an uneven social exchange can further lead to a range of unfavorable employee attitudes and behaviors, such as decreased helping behavior and performance as well as increased employee turnover (Cropanzano and Mitchell, 2005). 
TABLE $1^{\text {a }}$

CORRELATIONS

\begin{tabular}{|c|c|c|c|c|c|c|c|c|c|c|c|c|c|c|}
\hline & & 1 & 2 & 3 & 4 & 5 & 6 & 7 & 8 & 9 & 10 & 11 & 12 & 13 \\
\hline 1 & Organization 1 & & & & & & & & & & & & & \\
\hline 2 & Organization 2 & $-.538 * * *$ & & & & & & & & & & & & \\
\hline 3 & Education & .053 & -.070 & & & & & & & & & & & \\
\hline 4 & Age & .028 & $.103 *$ & -.059 & & & & & & & & & & \\
\hline 5 & $\begin{array}{l}\text { Gender }(0=\text { male, } \\
1=\text { female })\end{array}$ & $.110^{*}$ & -.044 & $-.203 * * *$ & .002 & & & & & & & & & \\
\hline 6 & Job-based pay & -.099 & -.095 & $.623 * *$ & $.179 * *$ & $-.394 * * *$ & & & & & & & & \\
\hline 7 & Merit pay & -.067 & $.350 * * *$ & -.019 & $.328 * * *$ & .027 & .088 & & & & & & & \\
\hline 8 & Pay change & $-.161 * *$ & .057 & $-.148 * *$ & $-.378 * * *$ & $.179 * *$ & .006 & -.036 & & & & & & \\
\hline 9 & $\begin{array}{l}\text { Favoritism in } \\
\text { performance } \\
\text { appraisal }\end{array}$ & $.112 *$ & -.038 & .059 & $.110^{*}$ & $.182 * *$ & -.078 & $.135^{*}$ & .003 & & & & & \\
\hline 10 & $\begin{array}{l}\text { Compression in } \\
\text { performance } \\
\text { appraisal }\end{array}$ & -.094 & .093 & $.148 * *$ & .011 & -.021 & $.199 * *$ & $.174 * *$ & .011 & .100 & & & & \\
\hline 11 & $\begin{array}{l}\text { Politics in pay } \\
\text { decisions }\end{array}$ & $.126^{*}$ & -.024 & -.065 & .084 & .104 & $-.205 * * *$ & .059 & $-.144 * *$ & $.274 * * *$ & $-.155 * *$ & & & \\
\hline 12 & Distributive justice & -.085 & -.067 & .049 & $-.111^{*}$ & -.098 & $.283 * * *$ & -.099 & $.118 *$ & $-.267 * * *$ & .105 & $-.498 * * *$ & & \\
\hline 13 & $\begin{array}{l}\text { Voice in pay system } \\
\text { development }\end{array}$ & $-.174 * *$ & -.093 & $.133^{*}$ & $-.142 *$ & -.104 & $.253 * * *$ & -.083 & $.159 * *$ & $-.169 * *$ & $.153^{*}$ & $-.416 * * *$ & $.404 * * *$ & \\
\hline 14 & $\begin{array}{l}\text { Pay system } \\
\text { effectiveness }\end{array}$ & $-.153 *$ & -.009 & -.083 & $-.162 * *$ & .057 & .006 & -.066 & $.134^{*}$ & $-.295 * * *$ & .079 & $-.547 * * *$ & $.419 * * *$ & $.323 * * *$ \\
\hline
\end{tabular}

${ }^{a}$ Notes. $\mathrm{N}=367 . * * * \mathrm{p}<0.001, * * \mathrm{p}<0.01, * \mathrm{p}<0.05$. 
TABLE $2^{\mathrm{b}}$

MEANS AND STANDARD DEVIATIONS

\begin{tabular}{lcccc}
\hline & Organization 1 & Organization 2 & Organization 3 & Total \\
\hline Favoritism in performance appraisal & $3.70(.76)$ & $3.53(.73)$ & $3.53(.82)$ & $3.61(.77)$ \\
Compression in performance appraisal & $2.56(.82)$ & $2.79(.90)$ & $2.67(.99)$ & $2.66(.89)$ \\
Politics in pay decisions & $3.64(.82)$ & $3.48(.97)$ & $3.34(.89)$ & $3.51(.89)^{*}$ \\
Voice in pay system development & $2.34(.88)$ & $2.40(1.05)$ & $3.04(1.21)$ & $2.56(1.08)^{* * *}$ \\
Distributive justice & $2.36(1.11)$ & $2.36(1.05)$ & $2.74(1.04)$ & $2.47(1.08)^{*}$ \\
Pay system effectiveness & $-0.26(.072)$ & $-0.14(.73)$ & $0.08(.65)$ & $-0.13(.72)^{* *}$ \\
\hline
\end{tabular}

${ }^{b}$ Notes. Scale $1-5$ where $1=$ strongly disagree, $3=$ not agree nor disagree, and $5=$ strongly agree for all other measures than pay system effectiveness for which it is from -2 to 2 where $-2=$ very negatively, $0=$ no effect, $2=$ very positively. One-way Anova $* \mathrm{p}<0.05, * * \mathrm{p}<.01$, $* * * \mathrm{p}<.001$ 
TABLE $3^{\mathrm{c}}$

HIERARCHICAL REGRESSION RESULTS FOR PAY SYSTEM EFFECTIVENESS

\begin{tabular}{|c|c|c|c|c|c|c|}
\hline & Step 1 & & Step 2 & & Step 3 & \\
\hline & $\beta$ & & $\beta$ & & $\beta$ & \\
\hline Organization 1 & -.17 & $*$ & -.13 & & -.13 & $*$ \\
\hline Organization 2 & -.08 & & -.09 & & -.07 & \\
\hline Education & -.16 & & -.05 & & -.03 & \\
\hline Age & -.18 & $*$ & -.09 & & -.05 & \\
\hline Gender $(0=$ male, $1=$ female $)$ & .10 & & .12 & & .11 & \\
\hline Job-based pay & .16 & & -.10 & & -.11 & \\
\hline Merit pay & .00 & & .06 & & -.02 & \\
\hline Pay change & .02 & & -.04 & & -.02 & \\
\hline Favoritism in performance appraisal & & & -.14 & $*$ & -.14 & $*$ \\
\hline Compression in performance appraisal & & & .02 & & .02 & \\
\hline Politics in pay decisions & & & -.42 & $* * *$ & -.40 & $* * *$ \\
\hline Distributive justice & & & .17 & $* *$ & .17 & $* *$ \\
\hline Voice in pay system development & & & .06 & & .07 & \\
\hline Politics in pay decisions * Distributive justice & & & & & .17 & $* *$ \\
\hline Politics in pay decisions $*$ Voice in pay system development & & & & & -.12 & $*$ \\
\hline Total $\mathrm{R}^{2}$ & .08 & * & .40 & $* * *$ & .42 & $* * *$ \\
\hline$\Delta \mathrm{R}^{2}$ Step & .08 & * & .32 & $* * *$ & .02 & * \\
\hline
\end{tabular}

${ }^{c}$ Note. $\mathrm{N}=367 .{ }^{* * *} \mathrm{p}<0.001,{ }^{* *} \mathrm{p}<0.01,{ }^{*} \mathrm{p}<0.05$ 
FIGURE 1

CONCEPTUAL MERIT PAY SYSTEM EFFECTIVENESS MODEL

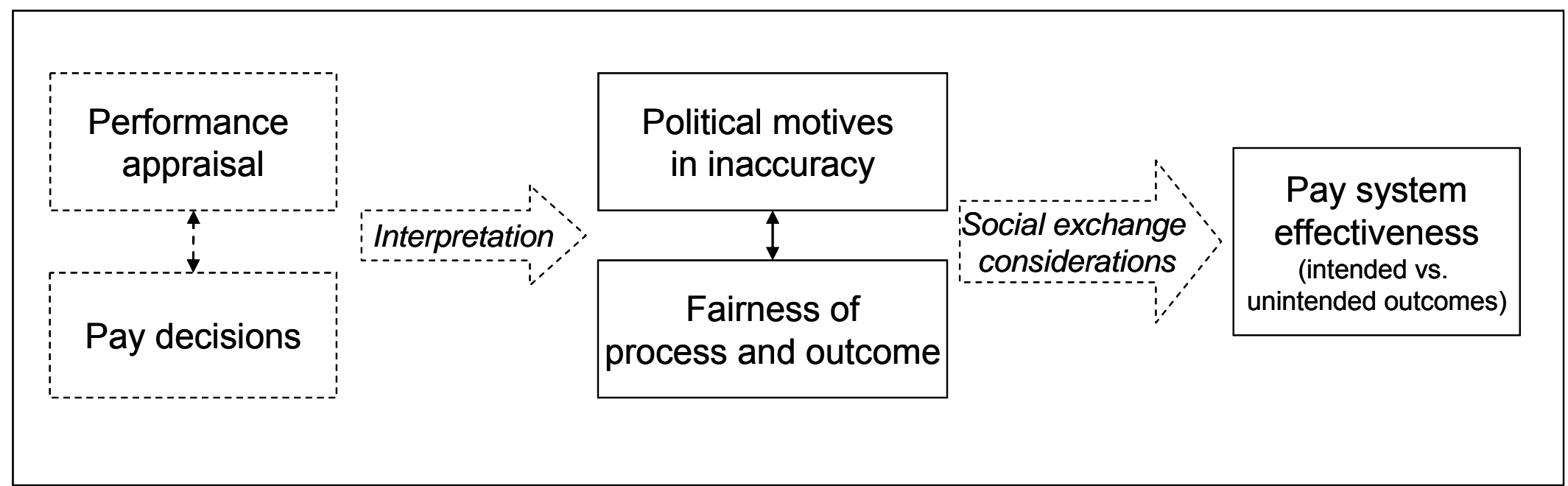


FIGURE $2^{\text {a }}$

PLOT OF THE INTERACTION OF PERCEPTIONS POLITICS AND DISTRIBUTIVE JUSTICE ON PAY SYSTEM EFFECTIVENESS

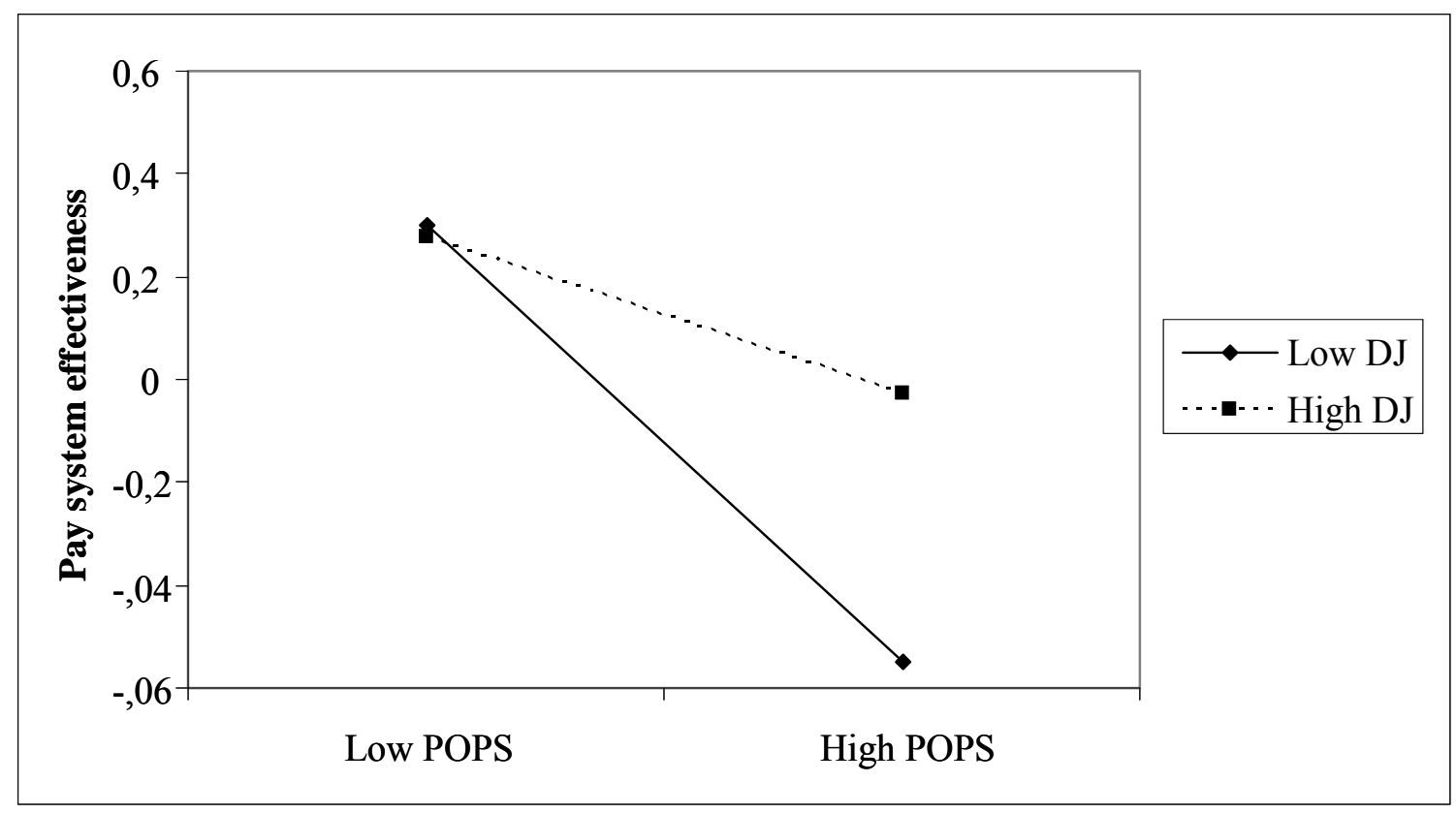

${ }^{\mathrm{a}}$ Note. POPS $=$ Politics in pay decisions; $\mathrm{DJ}=$ Distributive justice 
FIGURE $3^{\mathrm{b}}$

PLOT OF THE INTERACTION OF PERCEPTIONS POLITICS AND VOICE IN PAY SYSTEM DEVELOPMENT ON PAY SYSTEM EFFECTIVENESS

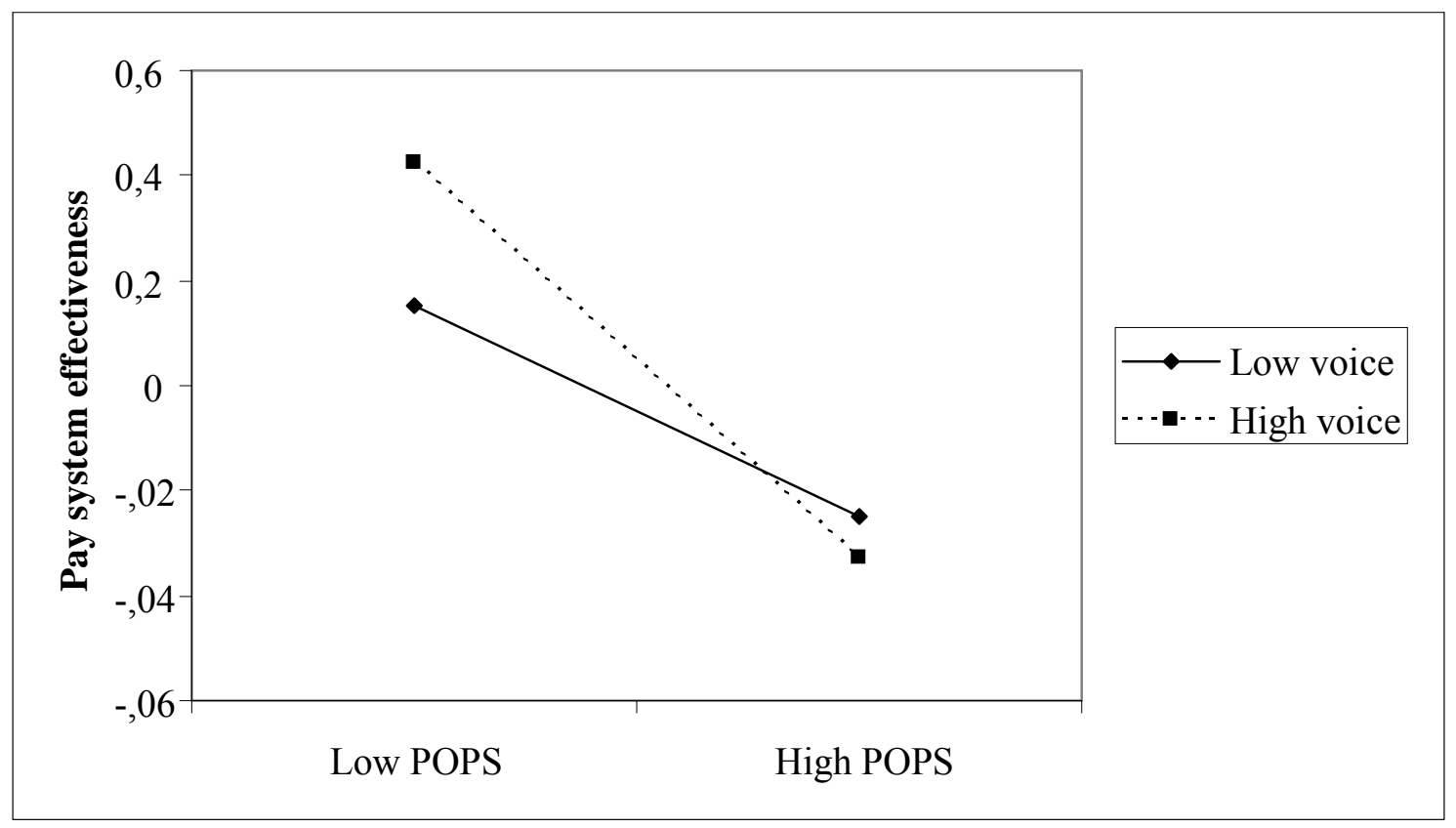

${ }^{\mathrm{b}}$ Note. POPS $=$ Politics in pay decisions; Voice $=$ Voice in pay system development 


\section{REFERENCES}

Adams, J. S. (1965). "Inequity in social exchange". In L. Berkowitz (Ed.), Advances in experimental social psychology. Academic Press, New York, pp.

Altman, S., Valenzi, E., and Hodgetts, R. M. (1985). Organizational behavior: Theory and practice Academic Press, Orlando, FL.

Ammetera, A. P., Douglas, C., Gardnera, W. L., Hochwarterb, W. A., and Ferris, G.

R. (2002), "Toward a political theory of leadership", The Leadership Quarterly, Vol.

13, pp. 751-796.

Andrews, M. C. and Kacmar, K. M. (2001), "Discriminating among organizational politics, justice, and support", Journal of Organizational Behavior, Vol. 22, pp. 347366.

Arvey, R. D. and Murphy, K. R. (1998), "Performance evaluation in work settings", Annual Review of Psychology, Vol. 49, pp. 1141-1168.

Aryee, S., Chen, Z. X., and Budhwarc, P. S. (2004), "Exchange fairness and employee performance: An examination of the relationship between organizational politics and procedural justice", Organizational Behavior \& Human Decision Processes, Vol. 94, pp. 1-14.

Bartol, K. M. and Martin, D. C. (1988), "Influences on managerial pay allocations: A dependency perspective", Personnel Psychology, Vol. 41, pp. 361-378.

Bartol, K. M. and Martin, D. C. (1990), "When politics pays: Factors influencing managerial compensation decisions", Personnel Psychology, Vol. 43, pp. 599-614. Baruch, Y. (1999), "Response rate in academic studies - A comparative analysis", Human Relations, Vol. 52, pp. 421-438. 
Beatty, J. R., McCune, J. T., and Beatty, R. W. (1988), "A policy-capturing approach to the study of United States and Japanese managers' compensation decisions", Journal of Management, Vol. 14, pp. 465-474.

Beer, M. and Cannon, M. D. (2004), "Promise and peril in implementing pay-forperformance", Human Resource Management, Vol. 43, pp. 3-48.

Blau, P. M. (1964). Exchange and power in social life, Wiley, New York.

Byrne, Z. S. (2005), "Fairness reduces the negative effects of organizational politics on turnover intentions, citizenship behavior and job performance", Journal of Business and Psychology, Vol. 20, pp. 175-200.

Campbell, D. J., Campbell, K. M., and Chia, H.-B. (1998), "Merit pay, performance appraisal, and individual motivation: An analysis and alternative", Human Resource Management, Vol. 37, pp. 113-146.

Chang, C.-H., Rosen, C. C., and Levy, P. E. (in press), "The relationship between perceptions of organizational politics and employee attitudes, strain, and behavior: A meta-analytic examination", Academy of Management Journal.

Chen, C. C. (1995), "New trends in rewards allocation preferences: A Sino-U.S. comparison", The Academy of Management Journal, Vol. 38, pp. 408-428.

Chiang, F. F. T. and Birtch, T. A. (2005), "A taxonomy of reward preference: Examining country differences", Journal of International Management, Vol. 11, pp. $357-375$.

Cohen-Charash, Y. and Spector, P. E. (2001), "The role of justice in organizations: A meta-analysis", Organizational Behavior and Human Decision Processes, Vol. 86, pp. $278-321$.

Colquitt, J. A. (2001), "On the dimensionality of organizational justice: A construct validation of a measure", Journal of Applied Psychology, Vol. 86, pp. 386-400. 
Colquitt, J. A., Conlon, D. E., Wesson, M. J., Porter, O. L. H., and Ng, K. Y. (2001), "Justice at the millennium: A meta-analytic review of 25 years of organizational justice research", Journal of Applied Psychology, Vol. 86, pp. 425-445.

Conlon, D. E., Meyer, C. J., and Nowakowski, J. M. (2005). "How does

organizational justice affect performance, withdrawal, and counterproductive behavior?" In J. Greenberg and J. A. Colquitt (Eds.), Handbook of organizational justice. Lawrence Erlbaum Associates, Mahwah, NJ, pp.

Cox, A. (2000), "The importance of employee participation in determining pay system effectiveness", International Journal of Management Reviews, Vol. 2, pp. 357-375. Cropanzano, R. and Mitchell, M. S. (2005), "Social exchange theory: An interdisciplinary review", Journal of Management, Vol. 31, pp. 874-900. Daly, J. P. and Geyer, P. D. (1994), "The role of fairness in implementing large-scale change: Employee evaluations of process and outcome in seven facility relocations", Journal of Organizational Behavior, Vol. 15, pp. 623-638.

Dipboye, R. L. and dePontbriand, R. (1981), "Correlates of employee reactions to performance appraisals and appraisal systems", Journal of Applied Psychology, Vol. 66, pp. $248-251$.

Dipboye, R. L. (1995). "How politics can destructure human resources management, support and justice". In R. S. Cropanzano and K. M. Kacmar (Eds.), Organizational politics, justice and support: Managing the social climate of the workplace. Quorum Books, Westport, CT, pp. 55-80.

Evans, M. G. (1985), "A Monte Carlo study of the effects of correlated method variance in moderated multiple regression analysis", Organizational Behavior and Human Decision Processes, Vol. 36, pp. 305-323. 
Fernie, S. and Metcalf, D. (1995), "Participation, contingent pay, representation and workplace performance: Evidence from Great Britain", British Journal of Industrial Relations, Vol. 33, pp. 379-415.

Ferris, G. R., Russ, G. S., and Fandt, P. M. (1989). "Politics in organizations". In R. A. Giacalone and P. Rosenfield (Eds.), Impression management in the organization. Erlbaum, Hillsdale, NJ, pp. 143-170.

Ferris, G. R. and Kacmar, K. M. (1992), "Perceptions of organizational politics", Journal of Management, Vol. 18, pp. 93-116.

Ferris, G. R., Frink, D. D., Beehr, T. A., and Gilmore, D. C. (1995). "Political fairness and fair politics: the conceptual integration of divergent constructs". In R. S.

Cropanzano and K. M. Kacmar (Eds.), Organizational politics, justice, and support: Managing the Social climate of the workplace. Quorum, Westport, CT, pp. 21-36. Ferris, G. R., Frink, D. D., Galang, M. C., Zhou, J., Kacmar, K. M., and Howard, J. L. (1996), "Perceptions of organizational politics: Prediction, stress-related Implications, and outcomes", Human Relations, Vol. 49, pp. 233-266.

Gabris, G. T. and Ihrke, D. M. (2000), "Improving employee acceptance toward performance appraisal and merit pay systems", Review of Public Personnel Administration, Vol. 20, pp. 41-53.

Gerhart, B. and Rynes, S. L. (2003). Compensation: Theory, evidence, and strategic implications, Sage, Thousand Oaks, CA.

Greene, C. N. and Podsakoff, P. M. (1981), "Effects of withdrawal of a performancecontingent reward on supervisory influence and power", The Academy of Management Journal, Vol. 24, pp. 527-542.

Gupta, N. and Jenkins, D. G. (1996), "Politics in pay", Compensation and Benefits Review, Vol. 28, pp. 23-31. 
Harrell-Cook, G., Ferris, G. R., Gerald, R., and Dulebohn, J. H. (1999), "Political behaviors as moderators of the perceptions of organizational politics-work outcomes relationships", Journal of Organizational Behavior, Vol. 20, pp. 1093-1105. Harris, K. J. and Kacmar, K. M. (2005), "Easing the strain: The buffer role of supervisors in the perceptions of politics-strain relationship", Journal of Occupational and Organizational Psychology, Vol. 78, pp. 337-354.

Harris, K. J., Andrews, M. C., and Kacmar, K. M. (2007), "The moderating effects of justice on the relationship between organizational politics and workplace attitudes", Journal of Business and Psychology, Vol. 22, pp. 135-144.

Harris, L. (2001), "Rewarding employee performance: Line managers' values, beliefs and perspectives", International Journal of Human Resource Management, Vol. 12, pp. 1182-1192.

Heneman, R. L. (1992). Merit pay: Linking pay increases to performance ratings, Addison-Wesley, New York.

Heneman, R. L. and Werner, J. M. (2006). Merit pay: Linking pay to performance in a changing world, Information Age Publishing, Greenwich, CT.

Hu, L.-T. and Bentler, P. M. (1999), "Cutoff criteria for fit indexes in covariance structure analysis: Conventional criteria versus new alternatives", Structural Equation Modeling, Vol. 6, pp. 1-55.

Jenkins, J., G.D. and Lawler, E. E. I. (1981), "Impact of employee participation in pay plan development", Organizational behavior and human performance, Vol. 28, pp. 111-128.

Kacmar, K. M. and Ferris, G. R. (1991), "Perceptions of organzational politics (POPS) scale: Development and construct validation", Educational and Psychological Measurement, Vol. 51, pp. 193-205. 
Kacmar, K. M. and Carlson, D. S. (1997), "Further validation of the perceptions of politics scale (POPS): A multiple sample investigation", Journal of Management, Vol. 23, pp. 627-658.

Kacmar, K. M. and Baron, R. A. (1999), "Organizational politics: The state of the field, links to related processes, and an agenda for future research", Research in Personnel and Human Resources Management Vol. 17, pp. 1-39.

Kellough, J. E. and Lu, H. (1993), "The paradox of merit pay in the public sector: Persistence of a problematic procedure", Review of Public Personnel Administration, Vol. 13, pp. 45-64.

Kleingeld, A., Van Tuijl, H., and Algera, J. A. (2004), "Participation in the design of performance management systems: A quasi-experimental field study", Journal of Organizational Behavior, Vol. 25, pp. 831-851.

Lefkowitz, J. (2000), "The role of interpersonal affective regard in supervisory performance ratings: A literature review and proposed causal model", Journal of Occupational \& Organizational Psychology, Vol. 73, pp. 67-85.

Levy, P. E. and Williams, J. R. (2004), "The social context of performance appraisal: A review and framework for the future", Journal of Management, Vol. 30, pp. 881905.

Longenecker, C. O., Sims, H. P., and Gioia, D. A. (1987), "Behind the mask: The politics of employee appraisal", Academy of Management Executive, Vol. 1, pp. 183193.

Mamman, A., Sulaiman, M., and Fadel, A. (1996), "Attitudes to pay systems: an exploratory study within and across cultures", The International Journal of Human Resource Management, Vol. 7, pp. 101-121. 
Marsden, D. and Richardson, R. (1994), "Performing for pay? The effects of 'merit pay' on motivation in a public service", British Journal of Industrial Relations, Vol. 32, pp. 243-261.

Miller, B. K., Rutherford, M. A., and Kolodinsky, R. W. (2008), "Perceptions of organizational politics: A meta-analysis of outcomes", Journal of Business and Psychology, Vol. 22, pp. 209-222.

Murphy, K. R. and Cleveland, J. N. (1995). Understanding performance appraisal: Social, organizational, and goal-oriented perspectives, Sage, Newbury Park, CA. Murphy, K. R., Cleveland, J. N., Skattebo, A. L., and Kinney, T. B. (2004), "Raters who pursue different goals give different ratings", Journal of Applied Psychology, Vol. 89, pp. 158-164.

Nishii, L. H., Lepak, D. P., and Schneider, B. (2008), "Employee attributions of the "why" of HR practices: Their effects on employee attitudes and behaviors, and customer satisfaction", Personnel Psychology, Vol. 61, pp. 503-545.

Nunnally, J. and Bernstein, I. (1994). Psychometric theory, McGraw Hill, New York. Perry, J. L., Engbers, T. A., and Jun, S. Y. (2008), "Back to the future? Performancerelated pay, empirical research, and the perils of persistence", Public Administration Review, Vol. January/February, pp. 39-51.

Pfeffer, J. (1981). Power in organizations, Pitman, Boston

Podsakoff, P. M., MacKenzie, S. B., Lee, J.-Y., and Podsakoff, N. P. (2003),

"Common method biases in behavioral research: A critical review of the literature and recommended remedies", Journal of Applied Psychology, Vol. 88, pp. 879-903. Poon, J. M. L. (2003), "Situational antecedents and outcomes of organizational politics perceptions", Journal of Managerial Psychology, Vol. 18, pp. 138-155. 
Poon, J. M. L. (2004), "Effects of performance appraisal politics on job satisfaction and turnover intention", Personnel Review, Vol. 33, pp. 322-334.

Poon, J. M. L. (2006), "Trust-in-supervisor and helping coworkers: Moderating effect of perceived politics", Journal of Managerial Psychology, Vol. 21, pp. 518-532.

Prendergast, C. and Topel, R. H. (1996), "Favoritism in organizations", Journal of Political Economy, Vol. 104, pp. 958-978.

Price, J. L. and Mueller, C. W. (1986). Handbook of organizational measurement, Pitman, Marshfield, MA.

Randall, M. L., Cropanzano, R., Bormann, C. A., and Birjulin, A. (1999),

"Organizational politics and organizational support as predictors of work attitudes, job performance, and organizational citizenship behavior", Journal of Organizational Behavior, Vol. 20, pp. 159-174.

Rynes, S. L., Gerhart, B., and Parks, L. (2005), "Personnel psychology: Performance evaluation and pay for performance", Annual Review of Psychology, Vol. 56, pp. 571600.

Shapiro, D. L. and Brett, J. M. (2005). "What is the role of control in organizational justice?" In J. Greenberg and J. A. Colquitt (Eds.), Handbook of organizational justice. Lawrence Erlbaum Associates, Mahwah, NJ, pp. 155-177.

Stone-Romero, E. F. and Stone, D. L. (2002), "Cross-cultural differences in responses to feedback", Research in Personnel and Human Resources Management, Vol. 21, pp. 275-331.

Stone, D. L. and Stone, E. F. (1985), "The effects of feedback consistency and feedback favorability on self-perceived task competence and perceived feedback accuracy ", Organizational Behavior \& Human Decision Processes, Vol. 36, pp. 167185. 
Stone, E. F. and Stone, D. L. (1984), "The effects of multiple sources of performance feedback on perceptions of task competence and feedback accuracy", Journal of Management, Vol. 10, pp. 371-378.

Thibaut, J. and Walker, L. (1975). Procedural justice: a psychological analysis, Lawrence Erlbaum Associates, Hillsdale, NJ.

Treadway, D. C., Adams, G. L., and Goodman, J. M. (2005), "The formation of political sub-climates: Predictions from social identity, structuration, and symbolic interaction", Journal of Business and Psychology, Vol. 20, pp. 201-219.

Tsui, A. and Barry, B. (1986), "Interpersonal affect and rating errors", Academy of Management Journal, Vol. 29, pp. 586-599.

Tziner, A., Latham, G. P., Price, B. S., and Haccoun, R. (1996), "Development and validation of a questionnaire for measuring perceived political considerations in performance appraisal", Journal of Organizational Behavior, Vol. 17, pp. 179-190. Tziner, A., Prince, J. B., and Murphy, K. R. (1997), "PCPAQ - The questionnaire for measuring perceived political considerations in performance appraisal: Some new evidence regarding its psychometric qualities", Journal of Social Behavior and Personality, Vol. 12, pp. 189-199.

Tziner, A. (1999), "The relationship between distal and proximal factors and the use of political considerations in performance appraisal", Journal of Business and Psychology, Vol. 14, pp. 217-231.

Tziner, A., Murphy, K. R., and Cleveland, J. N. (2005), "Contextual and rater factors affecting rating behavior", Group \& Organization Management, Vol. 30, pp. 89-98. Valle, M. and Perrewe, P. L. (2000), "Do politics perceptions relate to political behaviors? Test of an implicit assumption and expanded model", Human Relations, Vol. 52, pp. 359-386. 
Williams, M. L., McDaniel, M. A., and Nguyen, N. T. (2006), " A meta-analysis of the antecedents and consequences of pay level satisfaction", Journal of Applied Psychology, Vol. 91, pp. 392-413. 


\section{APPENDIX A}

\section{POLITICS AND FAIRNESS SURVEY ITEMS}

\section{Favoritism in performance appraisal}

Supervisors' performance ratings reflect in part their personal liking or disliking of employees

Supervisors' performance ratings are affected by the extent to which employees are perceived as sharing the same basic values as they do

Supervisors give performance ratings that will make them look good to their superiors

Compression in performance appraisal

Supervisors avoid giving performance ratings that may antagonize employees (e.g. a low rating)

Supervisors inflate performance ratings in order to maximize rewards offered to their employees (e.g. salary increases, promotions, prestigious assignments)

Supervisors are likely to give an inflated performance appraisal in order to avoid negative/uncomfortable feedback sessions with a subordinate

Politics in pay decisions

Promotions in this department generally go to top performers (reverse scored)

Rewards come only to those who work hard in this organization (reverse scored)

I can't remember when a person received a pay increase or a promotion that was inconsistent with the published policies (reverse scored)

Voice in pay system development

People like myself had input in the decision

Management did not give me a chance to express my concerns before they made the decision (reverse scored)

The organization did not listen to my views about the decision (reverse coded)

Before management made the decision, they asked me what I thought about the idea

Distributive justice

I'm fairly rewarded for the amount of effort that I put forth

I'm fairly rewarded for the work that I have done well

I'm fairly rewarded in view of the amount of experience I have

I'm fairly rewarded considering the responsibilities that I have

I'm fairly rewarded taking into account the amount of education and training that I

have had

I'm fairly rewarded for the stresses and strains of my job 